\title{
Severe tumefactive rebound of multiple sclerosis following fingolimod cessation
}

\author{
Sharfaraz Salam, ${ }^{1,2}$ Tatiana Mihalova, ${ }^{1}$ Rekha Siripurapu ${ }^{3}$
}

${ }^{1}$ Department of Neurology, Salford Royal NHS Foundation Trust, Salford, UK

${ }^{2}$ Pennine Acute Hospitals NHS Trust, Manchester, UK ${ }^{3}$ Department of Radiology, Salford Royal NHS Foundation Trust, Salford, UK

\section{Correspondence to} Dr Sharfaraz Salam, sharfaraz@doctors.org.uk

Accepted 12 May 2016

\section{DESCRIPTION}

Fingolimod is an oral sphingosine-1-phosphate receptor modulator approved for the treatment of active relapsing-remitting multiple sclerosis (RRMS). Recent reports have highlighted the possible risk of rebound disease activity after withdrawal of fingolimod. We describe a case of a patient who developed severe tumefactive lesions on discontinuing fingolimod treatment.

A 32-year-old woman with RRMS escalated treatment from interferon $\beta$ to fingolimod due to ongoing relapses. She developed side effects on fingolimod including persistent lymphopenia $(<0.3)$. The fingolimod dose was reduced to alternate days. The patient noticed cognitive decline with progressive memory loss. JC-virus serology was previously positive, with a titre of 2.41. Cerebrospinal (CSF) studies and MRI were performed to exclude progressive multifocal leukoencephalopathy (PML).
CSF JC-virus PCR was negative. MRI with contrast showed ongoing MS disease activity, but no evidence of PML.

We aimed to switch treatment from fingolimod to alemtuzumab. The patient discontinued fingolimod in May 2015. However, only by July 2015 did the side effects related to fingolimod resolve. The patient started a modified diet and low-dose naltrexone therapy. She now declined treatment with alemtuzumab, anticipating further side effects. However, she consented to repeat MRI in 2 months and further discussion to reconsider alemtuzumab was carried out.

In August 2015, she was admitted with a severe MS relapse. Examination revealed acute left hemisensory disturbance and tetraparesis. She also reported of dysphagia, weight loss, balance disturbance and worsening of memory. MRI demonstrated severe rebound disease and numerous contrast-enhancing tumefactive MS lesions (figures 1 and 2). She was

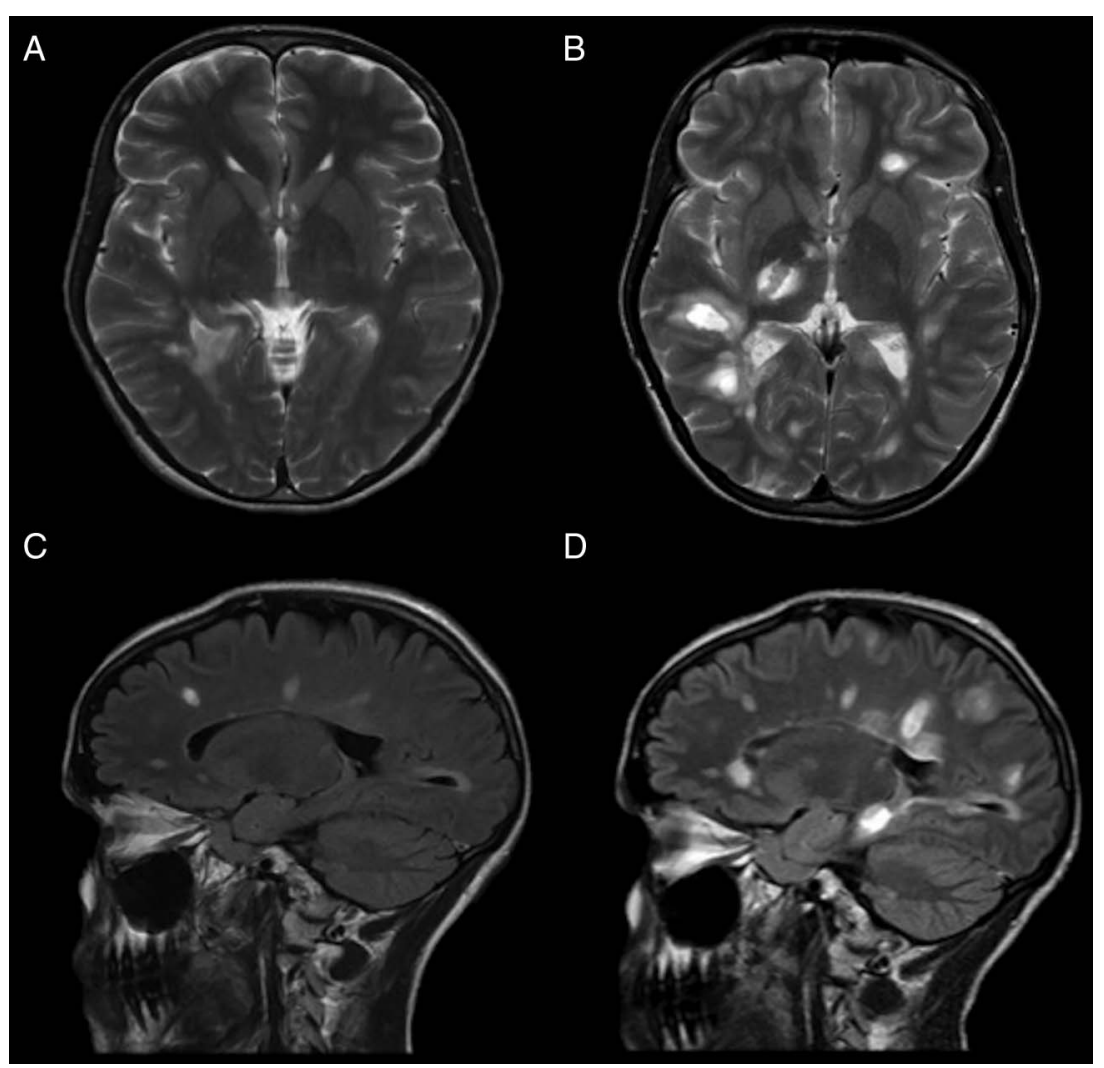

To cite: Salam $\mathrm{S}$, Mihalova T, Siripurapu R. BMJ Case Rep Published online: [please include Day Month Year] doi:10.1136/ bcr-2016-215596

Figure 1 (A) T2 axial images, performed in April 2015, showing a moderate number of periventricular white matter demyelinating lesions, (B) T2 axial images, performed in August 2015, illustrate multiple large active tumefactive lesions in the periventricular white matter and subcortical white matter evolving bilaterally frontal, parietal and temporal lobes, (C) FLAIR sagittal images, performed in April 2015, demonstrating periventricular white matter demyelination, (D) FLAIR sagittal images, performed in August 2015, show an increase in lesion load in the periventricular and subcortical white matter. FLAIR, fluid-attenuated inversion recovery. 


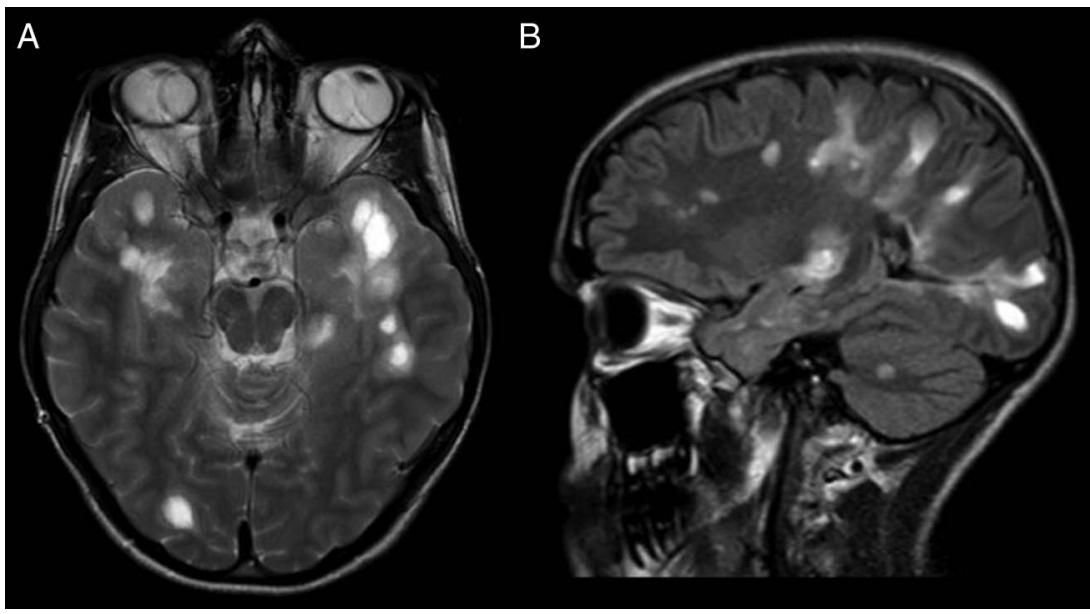

Figure 2 (A) T2 axial images and (B) FLAIR sagittal images showing extensive multifocal plaques, enhancing throughout both cerebral hemispheres, and tumefactive disease in the right posterior capsular region extending into the brainstem and cerebellum. FLAIR, fluid-attenuated inversion recovery.

treated with intravenous steroids and alemtuzumab leading to partial neurological recovery after 6 months.

Cessation of natalizumab has been associated with lifethreatening rebound of MS. However, such severe rebounds have rarely been reported after stopping fingolimod. ${ }^{12}$ Of such cases, tumefactive lesions are more infrequently described. ${ }^{1}$ Immunosuppression with steroids has been previously used to treat such relapses after fingolimod cessation. De Masi et $a l^{3}$

\section{Learning points}

- Although relapses following the cessation of fingolimod are uncommon, it is important to be aware of the potential risk and advise patients to not stop treatment abruptly.

- It is important to carefully plan switching from oral therapy in multiple sclerosis, avoiding prolonged periods without treatment. reported the use of selective immune adsorption (SIA) as an alternative to treat a patient with a relapse following cessation of fingolimod therapy. They considered SIA as the rebound was refractory to intravenous steroid therapy. Our patient stabilised on steroids and alemtuzumab.

Contributors SS was responsible for writing the manuscript and contributed to conception. TM supervised the writing and contributed to conception. RS was responsible for selection of images for the article.

Competing interests None declared.

Patient consent Obtained.

Provenance and peer review Not commissioned; externally peer reviewed.

\section{REFERENCES}

1 Faissner $S$, Hoepner $R$, Lukas $C$, et al. Tumefactive multiple sclerosis lesions in two patients after cessation of fingolimod treatment. Ther Adv Neurol Disord 2015;8:233-8

2 Havla JB, Pellkofer HL, Meinl I, et al. Rebound of disease activity after withdrawal of fingolimod (FTY720) treatment. Arch Neurol 2012;69:262-4.

3 De Masi R, Accoto $S$, Orlando $S$, et al. Dramatic recovery of steroid-refractory relapsed multiple sclerosis following fingolimod discontinuation using selective immune adsorption. BMC Neurol 2015;15:125

Copyright 2016 BMJ Publishing Group. All rights reserved. For permission to reuse any of this content visit http://group.bmj.com/group/rights-licensing/permissions.

BMJ Case Report Fellows may re-use this article for personal use and teaching without any further permission.

Become a Fellow of BMJ Case Reports today and you can:

- Submit as many cases as you like

- Enjoy fast sympathetic peer review and rapid publication of accepted articles

- Access all the published articles

- Re-use any of the published material for personal use and teaching without further permission

For information on Institutional Fellowships contact consortiasales@bmjgroup.com

Visit casereports.bmj.com for more articles like this and to become a Fellow 